\title{
Ironmaking System Including Coproduction of Carbon-Loaded Iron Oxide and Reformed Coke Oven Gas by Chemical Vapor Infiltration Process
}

\author{
Takahiro Nomura • Rochim B. Cahyono • \\ Tomohiro Akiyama
}

Published online: 14 February 2015

(C) The Minerals, Metals \& Materials Society (TMS) 2015

\begin{abstract}
Ironmaking system including coproduction of carbon-loaded iron oxide and reformed coke oven gas (COG) using coal tar, limonite ore, and waste heat is proposed to solve resource and energy problems in steelworks. In the proposed system, limonite ore, which is a low-grade iron ore with combined water, is first dehydrated to obtain a mesoporous solid. Then, during the chemical vapor infiltration, iron ore reduction, and reforming processes, the tar contained in the COG is deposited, leaving carbon in the mesopores of the ore. The ore is reduced by the COG and the tar is reformed by the combined sensible heat of the slag and COG, which acted as a heat source with the ore as a catalyst. The purpose of this study is to estimate the feasibility of the proposed system by process simulation using the Gibbs free energy minimization technique from the viewpoints of (1) the amount of coke required in steelworks, (2) the total chemical exergy of reformed COG, (3) the mass fraction of carbon deposited on carbon-loaded prereduced iron ore, and (4) available supplies of heat from the coke oven system to other systems under the reasonable assumptions given. The results of the analysis showed that, compared to the conventional ironmaking process, the proposed system can help decrease
\end{abstract}

This work was partly reviewed and approved as Hokkaido University Dissertation.

T. Nomura · R. B. Cahyono - T. Akiyama $(\bowtie)$

Center for Advanced Research of Energy Conversion Materials,

Hokkaido University, North 13 West 8, Kita-ku,

Sapporo 0608628, Japan

e-mail: takiyama@eng.hokudai.ac.jp

R. B. Cahyono

Department of Chemical Engineering, Gadjah Mada University,

Jl. Grafika 2, Bulaksumur, Yogyakarta 55281, Indonesia coke requirements by $9.62 \%$ and increase the total chemical exergy by $14.2 \%$.

Keywords Ironmaking - Chemical vapor infiltration . Exergy $\cdot$ Coproduction

\section{List of symbols}

$Q_{\text {coking }} \quad$ Amount of heat required for coking (MJ/tonpig-iron)

$Q_{\mathrm{COG}} \quad$ Available supplies of heat from COG (MJ/tonpig-iron)

$Q_{\mathrm{CDQ}} \quad$ Available supplies of heat from CDQ (MJ/tonpig-iron)

$Q_{\text {dehy }} \quad$ Amount of heat for dehydration of limonite (MJ/ton-pig-iron)

$Q_{\text {gas }} \quad$ Amount of available supplies of heat from reformed gas (MJ/ton-pig-iron)

$\eta_{\mathrm{C} \text {,dep }} \quad$ Ratio of deposited carbon (-)

$M_{\mathrm{C}, \mathrm{dep}} \quad$ Total mass of deposited carbon (kg/ton-pigiron)

$M_{\mathrm{C}, \text { tar }} \quad$ Total mass of carbon in tar (kg/ton-pig-iron)

$\mathrm{MF}_{\mathrm{C} \text {,sup }}$ Mass fraction of the deposited carbon on a (-) carbon-loaded and prereduced iron ore

$M_{\text {ore,re }} \quad$ Total mass of prereduced iron ore (kg/ton-pigiron)

$M_{\text {ore,in }} \quad$ Mass of input porous iron ore (kg/ton-pig-iron)

$M_{\text {coke }} \quad$ Amount of coke required (kg/ton-pig-iron)

$M_{\mathrm{Fe}_{3} \mathrm{O}_{4}} \quad$ Mass of magnetite (kg/ton-pig-iron)

$m_{\mathrm{w}, \mathrm{C}} \quad$ Molar weight of carbon $(\mathrm{g} / \mathrm{mol})$

$m_{\mathrm{w}, \mathrm{Fe}_{3} \mathrm{O}_{4}} \quad$ Molar weight of $\mathrm{Fe}_{3} \mathrm{O}_{4}(\mathrm{~g} / \mathrm{mol})$

$\varepsilon_{\text {total }} \quad$ Total chemical exergy (MJ/ton-pig-iron)

$\varepsilon_{\mathrm{COG}} \quad$ Chemical exergy of the COG (MJ/ton-pig-iron)

$\varepsilon_{\text {gas }} \quad$ Chemical exergy of reformed gas (MJ/ton-pigiron) 


$\begin{array}{ll}\varepsilon_{\mathrm{C}, \mathrm{dep}} & \begin{array}{l}\text { Chemical exergy of deposited carbon (MJ/ton- } \\ \text { pig-iron) }\end{array} \\ \varepsilon_{\text {ore }} & \begin{array}{l}\text { Chemical exergy of ore (MJ/ton-pig-iron) } \\ \varepsilon_{\mathrm{i}}\end{array} \\ \begin{array}{l}\text { Standard chemical exergy of a chemical species } \\ (\mathrm{MJ} / \mathrm{mol})\end{array} \\ Q_{\text {supply }} & \begin{array}{l}\text { Available supply of heat from the coke oven } \\ \text { system to the other systems. (MJ/ton-pig-iron) }\end{array} \\ T_{\text {ter }} & \begin{array}{l}\text { Terminal temperature }(\mathrm{K}) \\ \text { CDQ }\end{array} \\ \text { TRT } & \begin{array}{l}\text { Coke dry quenching } \\ \text { Top gas recovery turbines }\end{array} \\ \text { COG } & \text { Coke oven gas } \\ \text { CVI } & \text { Chemical vapor infiltration }\end{array}$

\section{Introduction}

Steelwork, which is one of the hugest industries, faces two main problems, depletion of high-grade resources [21] and energy. Because the amounts of high-grade ore and coal are decreasing, it is presumed that the price will increase. However, critical technologies to utilize low-grade resources have not been established yet. Despite energy recovery techniques such as coke dry quenching and top gas recovery turbines being widely applied [2], a huge amount of exhaust heat is generated from steelworks.

As a technology to utilize low-grade resources, our group has proposed biotar ironmaking [11, 12, 16, 17] which allows the use of low-grade carbon resource and low-grade iron ore without degradation or decrease in the volume of the product. This process can simultaneously yield carbon-loaded iron or iron oxide and clean gas from low-grade iron ore and biomass. Low-grade iron ores such as limonite, including $\mathrm{FeOOH}$, have rarely been used in steelworks, primarily because of their endothermic dehydration to form hematite $\left(\mathrm{Fe}_{2} \mathrm{O}_{3}\right)$. The hematite produced by dehydration of limonite is a mesoporous solid with a high-specific surface area [11]. Hata et al. [11] exposed the mesoporous ore to the vapors of nascent volatiles produced by the pyrolysis of woody biomass at $773 \mathrm{~K}$. The hematite was reduced to magnetite while tar was deposited in the mesopores, resulting in a carbon concentration up to $4 \mathrm{wt} \%$ of the resulting ore. Heating this carbon-loaded magnetite in an inert atmosphere up to $1173 \mathrm{~K}$ further reduced the ore, mainly by direct reduction, i.e., reduction by solid carbon; the ore thus produced had an $\mathrm{O} / \mathrm{Fe}$ atomic ratio of 0.81. Conversely, iron oxide is an attractive option for eliminating or reforming tar. The catalytic performance of iron oxide in reforming tar from biomass has been demonstrated by Uddin et al. [22] and Nordgreen et al. [19], who suggested the importance of specific surface area and oxidation states in catalytic performance. Kudo et al.
[17] continued the work in the field. They studied simultaneous production of carbon-loaded iron oxide and tarfree and reformed gas from low-grade natural iron ore and biomass. Recently, we have developed further the concept of biotar ironmaking to integrate the use of low- or highgrade coal [5, 7-9].

Many studies are reported to utilize high-temperature waste heat in steelworks. In particular, the high-temperature thermal energy of blast furnace slag is not always recovered despite its high potential energy [3]. Various other studies about the recovery of waste heat of slag were reviewed by Barati et al. [6]. Furthermore, it is well known that coke oven gas (COG) contains tar and that this tar causes clogging of the heat exchanger, making recovery of sensible heat from COG (over $1073 \mathrm{~K}$ ) difficult. Therefore, the sensible heat of the COG and the chemical exergy of the tar are not utilized in conventional ironmaking. To recover such hightemperature waste heat, Akiyama et al. [3]. suggested a thermochemical method. They presented various theoretical endothermic reactions such as steam reforming and dry reforming reactions that could occur with the use of hightemperature wastes as a heat source; their results indicated that the thermal energy of high-temperature wastes could be recuperated as chemical energy of $\mathrm{CO}$ and $\mathrm{H}_{2}$, which would be available as reduction gas for ironmaking. Additionally, Kasai et al. [15] and Li et al. [18], Qin et al. [20] proposed processes of steam reforming of methane and coal gasification, respectively, using waste heat from molten slag.

In addition, it is important to design a waste heat recovery system for ironmaking that will reduce not only fossil fuel consumption but also raw material inputs, since the purpose of the steelmaking industry is to achieve the most efficient production of steel. However, there were few studies that focused on both viewpoints.

Given these circumstances, we propose a new system that simultaneously produces carbon-loaded iron oxide and reforms the coal tar and COG using low-grade iron ore, COG with tar, the sensible heat of the COG, and waste heat from slag. Figure 1 is a schematic diagram of the proposed system. First, limonite ore (which is low-grade iron ore with combined water) is dehydrated to obtain a mesoporous solid. Second, the tar contained in the COG is deposited during the chemical vapor infiltration $(\mathrm{CVI})$, iron ore reduction, and reforming processes, leaving carbon in the mesopores of the ore. The ore is reduced by the COG and the tar is reformed by the combined sensible heat of the slag and COG, which acts as a heat source, with the ore as a catalyst. The proposed system is a type of thermochemical method from the viewpoint of waste heat recovery and can produce iron using the sensible heat of the COG and chemical exergy of the tar in combination with the limonite ore and waste heat of the slag. As a result, it could allow the realization of coproduction of carbon-loaded iron oxide 


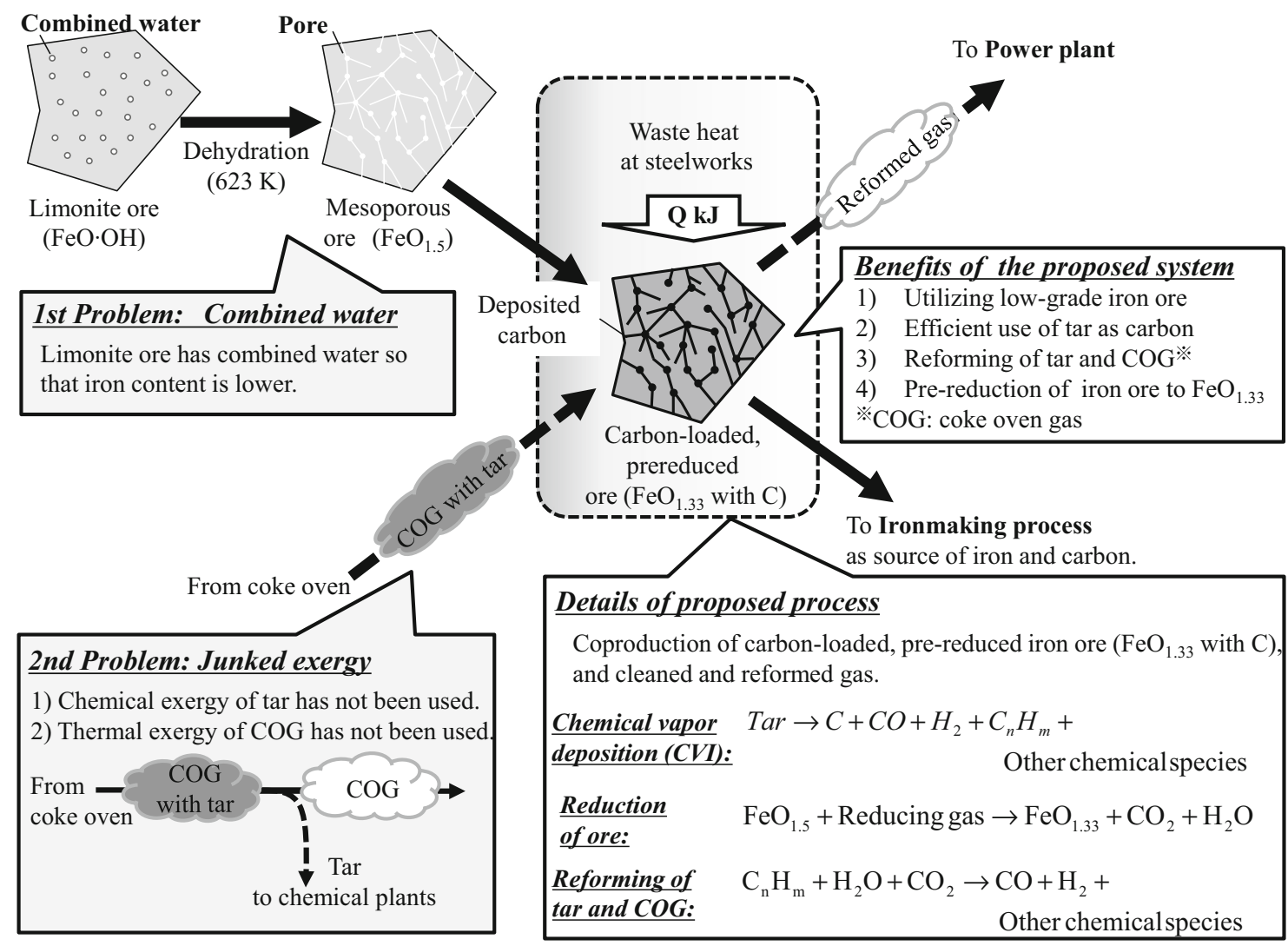

Fig. 1 Schematic diagram of the proposed system and problems in the conventional ironmaking process

and reformed COG and has great potential for reduction of the consumption of high-grade coal and ore.

The purpose of this study is to estimate the feasibility of the proposed system by process simulation. The proposed process is analyzed on the basis of the following criteria: (1) the requirement for cokes, (2) the total chemical exergy, (3) the mass fraction of carbon deposited onto the carbonloaded and prereduced iron ore, and (4) the supplies of heat from the coke oven system that are available to other systems under reasonable assumptions.

\section{Details of System Analysis}

We defined the boundary of the analysis to include the coke oven system and the ironmaking system. Conventional system: Case 1 and Proposed system: Case 2 including CVI process were analyzed.

\section{Conventional System: Case 1}

Figure 2 shows a process system diagram [14] for a conventional ironmaking system, without recovery of the tar, sensible heat of the COG, or waste heat of the slag. First, the coal is dry-distillated at about $1273 \mathrm{~K}$ and then hot coke is produced in the coke oven. Simultaneously, COG with tar is generated as a byproduct. Next, the sensible heat of the hot coke is recovered by coke dry quenching (CDQ) and, finally, the coke is supplied to the blast furnace. CDQ is effective for recovering waste heat and decreasing fossil fuel consumption. However, the hot COG with tar is quickly cooled and separated, so that the sensible heat of the COG and chemical exergy of the tar is wasted in conventional ironmaking systems.

\section{Proposed System: Case 2}

Figure 3 shows the process system diagram for the proposed ironmaking system, in which COG and dehydrated porous iron ore are provided for the $\mathrm{CVI} / \mathrm{Reduction} / \mathrm{Re}$ former process, with hot slag as the heat source. The unique aspect of this ironmaking system is the use of the sensible heat of the COG, chemical exergy of the tar, limonite ore, and waste heat of the slag. First, limonite ore was dehydrated at $723 \mathrm{~K}$ [11] to obtain a mesoporous solid. The reaction proceeded as follows:

Dehydration of limonite

$$
\begin{aligned}
& 2 \mathrm{FeOOH} \rightarrow \mathrm{Fe}_{2} \mathrm{O}_{3}+\mathrm{H}_{2} \mathrm{O} \\
& \quad \Delta H=49.8 \mathrm{~kJ} / 1 \mathrm{~mol}-\mathrm{Fe}_{2} \mathrm{O}_{3} \text { at } 723 \mathrm{~K}
\end{aligned}
$$


Fig. 2 Process system diagram of a conventional ironmaking system. Case 1: without recovery of the tar, sensible heat of the COG, and waste heat of the slag. Open circles processes; solid arrows flow of substances; dashed arrows flow of intermediary energy; dotted line system boundary
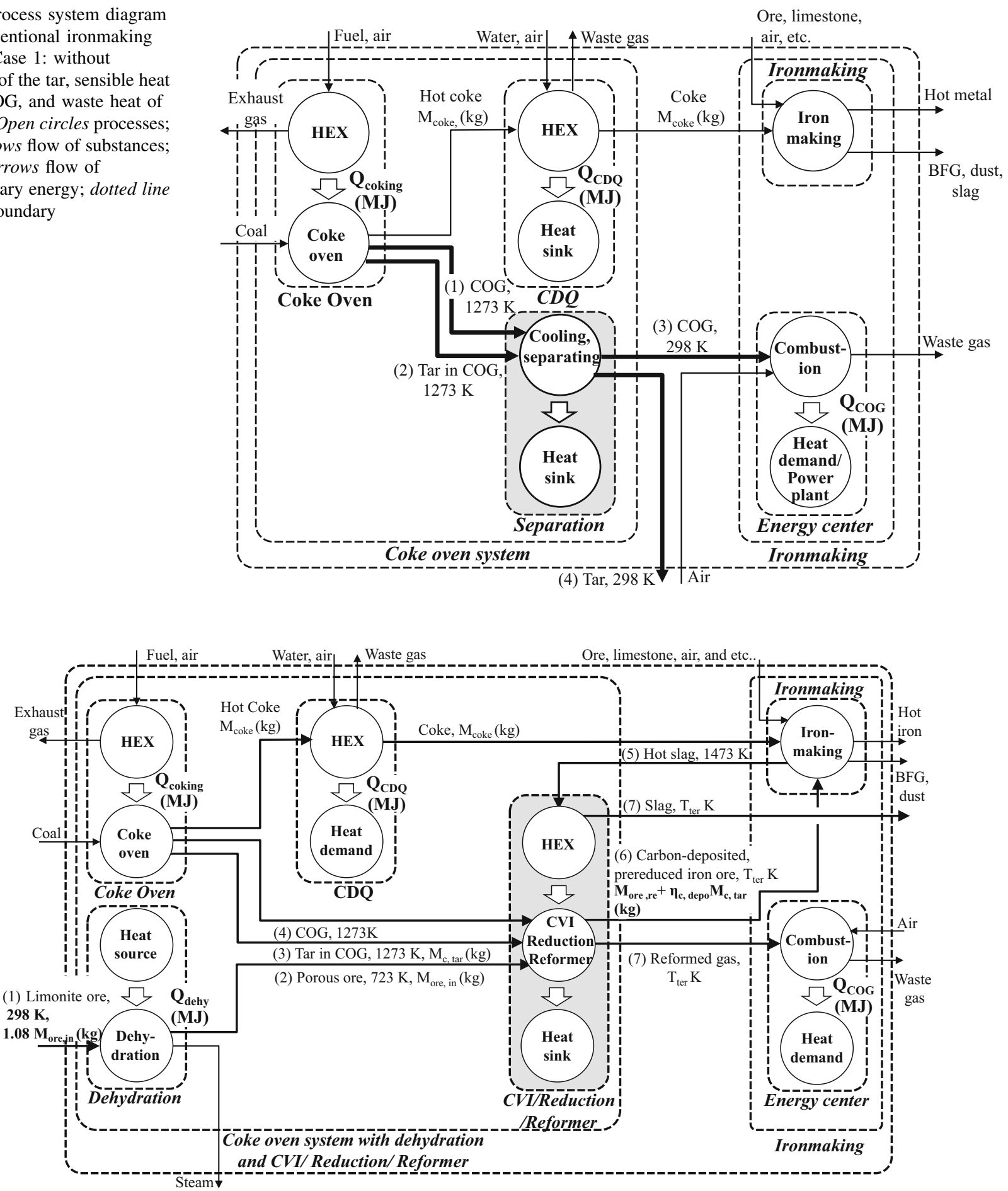

Fig. 3 Process system diagram of the proposed ironmaking system, Case 2, in which COG and dehydrated, porous iron ore are provided for the $\mathrm{CVI} /$ reduction/reformer process, with hot slag as a heat source

Then, in the CVI/Reduction/Reforming process, the tar contained in the COG was deposited, leaving carbon in the mesopores of the ore. The ore was reduced by the COG, and the tar was reformed by the combined sensible heat of the slag and COG, which acted as a heat source, with the ore as a catalyst.

The main reactions in the process proceeded as follows:

Decomposition of tar 
Tar $\rightarrow \mathrm{C}+\mathrm{C}_{n} \mathrm{H}_{m}+$ Other chemical species

Reduction of iron ore by reducing gas

1.5 $\mathrm{Fe}_{2} \mathrm{O}_{3}+$ Reducing gas $\rightarrow \mathrm{Fe}_{3} \mathrm{O}_{4}+\mathrm{a} \mathrm{CO}_{2}+\mathrm{bH}_{2} \mathrm{O}$

Reforming process

$a \mathrm{C}_{n} \mathrm{H}_{m}+b \mathrm{H}_{2} \mathrm{O}+c \mathrm{CO}_{2} \rightarrow e \mathrm{CO}+f \mathrm{H}_{2}$

The proposed system can use the sensible heat of the COG and chemical exergy of the tar in combination with the limonite ore and waste heat of the slag in an ironmaking system.

\section{Calculation Method}

We performed process simulations of the two cases under the following assumptions:

(1) The numbered streams in Figs. 2 and 3 were explicitly analyzed. Table 1 [1, 12, 13] lists the initial operating data for the integrated steelworks assumed in the study. Here, $Q_{\text {coking }}$ was calculated based on coke being heated from 298 to $1273 \mathrm{~K}$ with $15 \%$ heat loss. $Q_{\mathrm{CDQ}}$ was calculated based on the sensible heat of coke recovered from a change from 1273 to $773 \mathrm{~K}$. In the conventional system, the compositions of the COG were fixed in the ratio of $\mathrm{COG}$ to pig-iron of final product described in Table 1, and they were the same before and after the cooling and separation process. The temperatures of the COG and tar after the process were $298 \mathrm{~K}$.

(2) The compositions of the streams after the CVI process were equilibrium compositions that were determined using the Gibbs free energy minimization technique. This technique is based on the fact that the system is thermodynamically favorable when its total Gibbs free energy is at its minimum value and its differential is zero for a given temperature and pressure $[4,10]$. The temperatures of the materials in each output stream were given as terminal temperatures, $\mathrm{T}_{\text {ter }}$, based on heat and mass balances. The following chemical species were considered: $\mathrm{CH}_{4}$, $\mathrm{C}_{2} \mathrm{H}_{4}, \mathrm{C}_{2} \mathrm{H}_{6}, \mathrm{C}_{6} \mathrm{H}_{6}, \mathrm{C}_{7} \mathrm{H}_{8}, \mathrm{C}_{8} \mathrm{H}_{10}, \mathrm{C}_{10} \mathrm{H}_{8}, \mathrm{C}_{6} \mathrm{H}_{6} \mathrm{O}$, $\mathrm{C}_{20} \mathrm{H}_{12}, \mathrm{C}_{14} \mathrm{H}_{10}, \mathrm{CO}, \mathrm{CO}_{2}, \mathrm{H}_{2}, \mathrm{H}_{2} \mathrm{O}, \mathrm{H}_{2} \mathrm{~S}, \mathrm{O}_{2}, \mathrm{~N}_{2}$, $\mathrm{Fe}_{2} \mathrm{O}_{3}$, and $\mathrm{Fe}_{3} \mathrm{O}_{4}$.

(3) The components of the tar expected to form the carbon deposits were $\mathrm{CH}_{4}, \mathrm{C}_{2} \mathrm{H}_{4}, \mathrm{C}_{2} \mathrm{H}_{6}, \mathrm{C}_{6} \mathrm{H}_{6}, \mathrm{C}_{7} \mathrm{H}_{8}$, $\mathrm{C}_{8} \mathrm{H}_{10}, \mathrm{C}_{10} \mathrm{H}_{8}, \mathrm{C}_{6} \mathrm{H}_{6} \mathrm{O}, \mathrm{C}_{20} \mathrm{H}_{12}, \mathrm{C}_{14} \mathrm{H}_{10}, \mathrm{CO}, \mathrm{CO}_{2}$, $\mathrm{H}_{2}, \mathrm{H}_{2} \mathrm{O}, \mathrm{H}_{2} \mathrm{~S}, \mathrm{O}_{2}$, and $\mathrm{N}_{2}$.

(4) The deposited carbon was not considered in the equilibrium calculation, and direct reduction of ore by deposited carbon was not considered.

(5) The chemical exergy and thermal exergy were considered. The total exergy of each stream was calculated by the following equation:

$\varepsilon=\sum n_{\mathrm{i}} \varepsilon_{\mathrm{c}, \mathrm{i}}+\sum n_{\mathrm{i}} C_{\mathrm{p}, \mathrm{i}}\left(T-T_{0}-T_{0} \ln \frac{T}{T_{0}}\right)$

where $\varepsilon, n_{\mathrm{i}}, \varepsilon_{\mathrm{c}, \mathrm{i}}, C_{\mathrm{p}, \mathrm{i}}, T$, and $T_{0}$ are total exergy of a stream, molar quantity of a chemical species, chemical exergy, specific heat, temperature, and reference temperature, respectively. Table 2 lists the standard chemical exergy of each chemical component.

(6) The coke included 92 mass $\%$ of $\mathrm{C}$ and 8.0 mass $\%$ of ash. $1 \mathrm{~mol}$ of $\mathrm{C}$ can reduce $1.5 \mathrm{~mol}$ of $\mathrm{O}$ in iron ore, because (mol fraction of $\mathrm{CO}) /\left(\mathrm{mol}\right.$ fraction of $\left.\mathrm{CO}_{2}\right)$ of blast furnace gas is generally about 1.0.

Table 1 Initial operating data of the integrated steelworks assumed in the study

\begin{tabular}{ll}
\hline Coke (not including coke breeze) & $385 \mathrm{~kg} / \mathrm{t}$-pig-iron ${ }^{\mathrm{a}}, \mathrm{C} / \mathrm{Ash}(\mathrm{mass} \%)=92 / 8, C_{\mathrm{p}}=1.53 \mathrm{~kJ} /(\mathrm{kg} \mathrm{K})$ \\
Blast furnace slag & $287 \mathrm{~kg} / \mathrm{t}$-pig-iron ${ }^{\mathrm{a}}, C_{\mathrm{p}}=1.26 \mathrm{~kJ} /(\mathrm{kg} \mathrm{K}), 1473 \mathrm{~K}$ \\
Combined water of limonite ore & $8.09 \mathrm{mass} \%{ }^{\mathrm{b}}$ \\
Porous ore & $\mathrm{Fe}_{2} \mathrm{O}_{3} / \mathrm{Slag}(\mathrm{mass} \%)=78.0 / 22.0$ \\
Coke oven gas $(\mathrm{COG})$ & $\mathrm{H}_{2} / \mathrm{CH}_{4} / \mathrm{CO} / \mathrm{N}_{2} / \mathrm{CO}_{2} / \mathrm{C}_{2} \mathrm{H}_{4} / \mathrm{C}_{2} \mathrm{H}_{6} / \mathrm{O}_{2}(\mathrm{vol} \%$-drygas $)=$ \\
& $53.6 / 29.2 / 6.90 / 5.90 / 2.60 . / 1.50 / 0.200 / 0.100$ \\
& $218.2 \mathrm{Nm}^{3}$-dry gas $/ \mathrm{t}$-pig-iron, $\mathrm{H}_{2} \mathrm{O}=19.5 \mathrm{~kg} / \mathrm{t}$-pig-iron, $1273 \mathrm{~K}$ \\
Coal tar & Lower calorific value: $37.3 \mathrm{MJ} / \mathrm{kg}^{\mathrm{c}}$ \\
& $\mathrm{C} / \mathrm{H} / \mathrm{N} / \mathrm{S} / \mathrm{O}$ (mass $\%)=93.1 / 4.77 / 1.16 / 0.63$ \\
& $25.5 \mathrm{~kg} / \mathrm{t}$-pig-iron, $1273 \mathrm{~K}$ \\
$Q_{\text {Coking }}$ & $1.76 \mathrm{GJ} / \mathrm{t}-\mathrm{Coke}$ \\
$Q_{\mathrm{CDQ}}$ & $766 \mathrm{MJ} / \mathrm{t}-\mathrm{Coke}$ \\
\hline
\end{tabular}

a $[13]$

b $[12]$

c [1] 
Table 2 Standard chemical exergy of each chemical component

\begin{tabular}{ll}
\hline Material & $\varepsilon_{\mathrm{i}}(\mathrm{kJ} / \mathrm{mol})$ \\
\hline $\mathrm{CH}_{4}$ & 832 \\
$\mathrm{H}_{2}$ & 236 \\
$\mathrm{CO}$ & 275 \\
$\mathrm{CO}_{2}$ & 19.9 \\
$\mathrm{~N}_{2}$ & 0.720 \\
$\mathrm{O}_{2}$ & 3.97 \\
$\mathrm{C}_{2} \mathrm{H}_{4}$ & 1361 \\
$\mathrm{C}_{2} \mathrm{H}_{6}$ & 1496 \\
$\mathrm{H}_{2} \mathrm{O}$ & 9.50 \\
$\mathrm{H}_{2} \mathrm{~S}$ & 812 \\
$\mathrm{C}_{6} \mathrm{H}_{6} \mathrm{O}$ & 3304 \\
$\mathrm{C}_{7} \mathrm{H}_{8}$ & 3931 \\
$\mathrm{C}_{8} \mathrm{H}_{10}$ & 4588 \\
$\mathrm{C}_{10} \mathrm{H}_{8}$ & 5255 \\
$\mathrm{C}_{6} \mathrm{H}_{6} \mathrm{O}$ & 3129 \\
$\mathrm{C}_{20} \mathrm{H}_{12}$ & 10,031 \\
$\mathrm{C}_{14} \mathrm{H}_{10}$ & 7218 \\
\hline
\end{tabular}

(7) $1 \mathrm{~kg}$ of deposited carbon can reduce $1 \mathrm{~kg}$ of $\mathrm{C}$, therefore, $1 \mathrm{~kg}$ of deposited carbon can reduce $25 / 23(=100 / 92) \mathrm{kg}$ of coke.

(8) To analyze and evaluate the systems, the following values were defined.

(i) The mass of input porous iron ore: $M_{\text {ore,in }}$ $M_{\text {ore,in }}$ means the mass of input porous iron ore after dehydration of limonite ore. This analysis used $M_{\text {ore,in }}$ as a parameter.

(ii) The ratio of deposited carbon: $\eta_{\mathrm{C} \text {,dep }}$

$\eta_{\mathrm{C}, \mathrm{dep}}=\frac{M_{\mathrm{C}, \mathrm{dep}}}{M_{\mathrm{C}, \mathrm{tar}}}$

where $M_{\mathrm{C} \text {,dep }}$ and $M_{\mathrm{C} \text {,tar }}$ are the total mass of deposited carbon and the total mass of carbon in the tar, respectively. In the analysis, $\eta_{\mathrm{C} \text {,dep }}$ was set as a parameter

(iii) The mass fraction of the deposited carbon on a carbon-loaded and prereduced iron ore, $\mathrm{MF}_{\mathrm{C} \text {,sup }}$, was obtained as follows:

$\mathrm{MF}_{\mathrm{C}, \text { sup }}=\frac{M_{\mathrm{C}, \mathrm{dep}}}{M_{\text {ore,re }}+M_{\mathrm{C}, \mathrm{dep}}}$

where $M_{\text {ore,re }}$ is the total mass of prereduced iron ore. The sum of $M_{\text {ore,re }}$ and $M_{\mathrm{C}, \mathrm{dep}}$, the denominator on the right side of the above equation, represents the total mass of carbon-loaded and prereduced iron ore. In the analysis, was an important value used to estimate whether or not the conditions of the proposed system were possible, by comparison with some reported value.

(iv) The amount of coke required in the proposed system

$$
\begin{aligned}
& \left(M_{\text {coke }} \text { in proposed system }\right) \\
& =\left(M_{\text {coke }} \text { in conventional system }\right) \\
& \quad-\frac{25}{23}\left(M_{\mathrm{C}, \mathrm{dep}}-\frac{1}{3} \frac{m_{\mathrm{w}, \mathrm{C}} M_{\mathrm{Fe}_{3} \mathrm{O}_{4}}}{m_{\mathrm{w}, \mathrm{Fe}_{3} \mathrm{O}_{4}}}\right),
\end{aligned}
$$

where $M_{\text {coke }}, M_{\mathrm{Fe}_{3} \mathrm{O}_{4}}, m_{\mathrm{w}, \mathrm{C}}, m_{\mathrm{w}, \mathrm{Fe}_{3} \mathrm{O}_{4}}$ are the amounts of coke required, mass of $\mathrm{Fe}_{3} \mathrm{O}_{4}$ after the $\mathrm{CVI} /$ reduction/reformer process, molar weight of $\mathrm{C}$, and molar weight of $\mathrm{Fe}_{3} \mathrm{O}_{4}$, respectively. The second term on the right side reflects the reduction of coke by the deposited carbon based on the assumptions (6) and (7). The third term on the right side is the coke equivalent of producing $\mathrm{Fe}_{3} \mathrm{O}_{4}$ by reduction of $\mathrm{Fe}_{2} \mathrm{O}_{3}$, calculated on the assumptions (6) and (7), and the following equation:

$$
\begin{aligned}
\frac{3}{2} \mathrm{Fe}_{2} \mathrm{O}_{3}+\frac{1}{3} \mathrm{C} \rightarrow & \mathrm{Fe}_{3} \mathrm{O}_{4} \\
& +\frac{1}{3}\left(\frac{1}{2} \mathrm{CO}+\frac{1}{2} \mathrm{CO}_{2}\right) .
\end{aligned}
$$

(v) Total chemical exergy: $\varepsilon_{\text {total }}$

In the conventional system:

$\varepsilon_{\text {total }}=\varepsilon_{\mathrm{COG}}$

In the proposed system:

$\varepsilon_{\text {total }}=\varepsilon_{\text {gas }}+\varepsilon_{\mathrm{C}, \mathrm{dep}}+\varepsilon_{\text {ore,re }}$

where $\varepsilon_{\mathrm{COG}}, \varepsilon_{\text {gas }}, \varepsilon_{\mathrm{C} \text {,dep }}$, and $\varepsilon_{\text {ore,re }}$ are the chemical exergy of the COG, reformed gas, deposited carbon, and reduced ore, respectively, after the CVI/reduction/reformer process.

(vi) The available supply of heat from the coke oven system to the other systems, i.e., $Q_{\text {supply }}$ can be obtained as follows.

In the conventional system:

$O_{\text {supply }}=O_{\mathrm{CDQ}}+O_{\mathrm{COG}}-O_{\text {coking }}$

In the proposed system:

$Q_{\text {supply }}=Q_{\mathrm{CDQ}}+Q_{\mathrm{gas}}-Q_{\text {coking }}$

where $Q_{\text {coking }}, Q_{\mathrm{CDQ}}, Q_{\mathrm{COG}}$, and $Q_{\mathrm{gas}}$ are the amount of heat required for coking and the available supplies of heat from the CDQ, the COG in the conventional process, and the reformed gas in the proposed process, respectively. 
The coke oven system is not only a coking system but also an energy supply system. $Q_{\text {supply }}$ in the proposed system must exceed the supply in the conventional system, because a smaller $Q_{\text {supply }}$ would cause an overall shortage of heat in the ironmaking system. $Q_{\text {supply }}$ strongly depends on the mass of coke produced per ton of pig-iron. Therefore, $Q_{\text {supply }}$ represents a constraint with respect to the effectiveness of the proposed system. The proposed system can be established only if the following condition is satisfied:

$Q_{\text {supply }}($ Proposed $) \geq Q_{\text {supply }}($ Conventional $)$

\section{Results and Discussion}

Figure 4 shows the effects of $M_{\text {ore,in }}$ and $\eta_{\mathrm{C} \text {,dep }}$ on amounts of (a) $\mathrm{CH}_{4}$, (b) $\mathrm{H}_{2}$, and (c) $\mathrm{CO}$, and $T_{\text {ter }}$ of the reformed gas after the CVI/reduction/reformer process in the proposed system (Case 2). These parameters were most important in formulating an understanding of the system in terms of chemical reactions. $T_{\text {ter }}$ decreased as $M_{\text {ore,in }}$ increased, primarily because total heat contents of ore increased as $M_{\text {ore,in }}$ increased. The amount of $\mathrm{CH}_{4}$ had minimal value in each $\eta_{\mathrm{C} \text {,dep }}$, while amounts of $\mathrm{H}_{2}$ and $\mathrm{CO}$ had maximal value. These mean that steam reforming and dry reforming (such as in Eq. 4) occurred mainly for small values of $M_{\text {ore,in }}$ where reaction temperatures were high. Conversely, a methanation reaction occurred for large values of $M_{\text {ore,in }}$ where reaction temperatures were low. The methanation reaction can be described as follows.

$2 \mathrm{CO}+2 \mathrm{H}_{2} \rightarrow \mathrm{CH}_{4}+\mathrm{CO}_{2}$

$\mathrm{CO}+3 \mathrm{H}_{2} \rightarrow \mathrm{CH}_{4}+\mathrm{H}_{2} \mathrm{O}$

These results indicate that smaller values of $M_{\text {ore,in }}$ are advantageous for gas reforming.

Figure 5 illustrates the chemical exergy of gas, deposited carbon, and reduced ore for the production of 1 ton of coke. Here, $M_{\text {ore,in }}=0$ refers to the conventional process. Total chemical exergy in the proposed system was larger than that in the conventional system, although the values in each system were remarkably constant regardless of conditions. These results clearly show that the chemical exergy of coal can be used effectively by applying it in the proposed

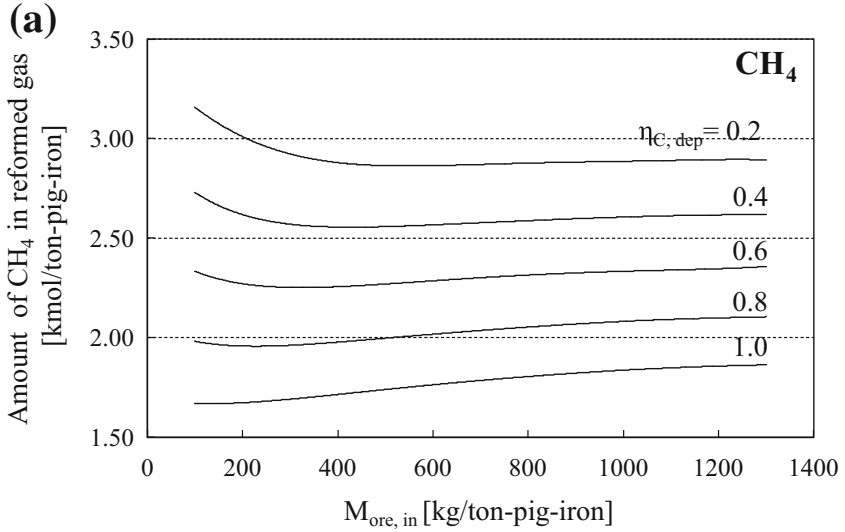

(c)

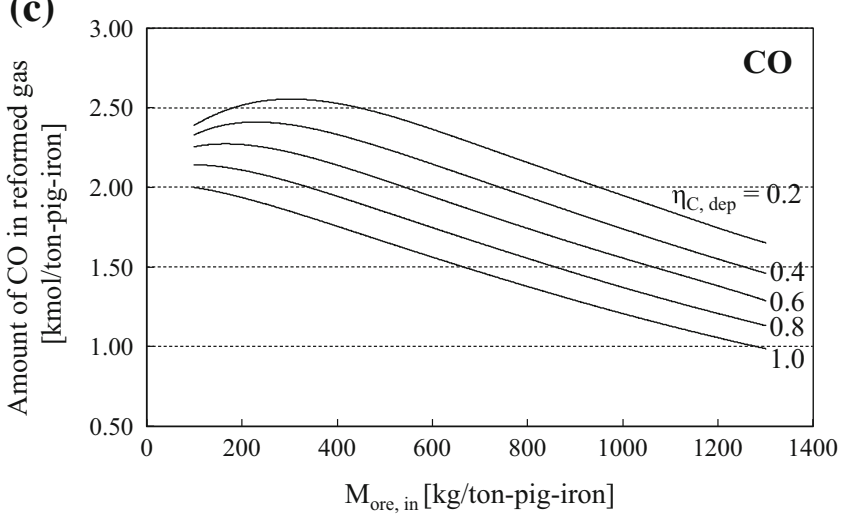

(b)

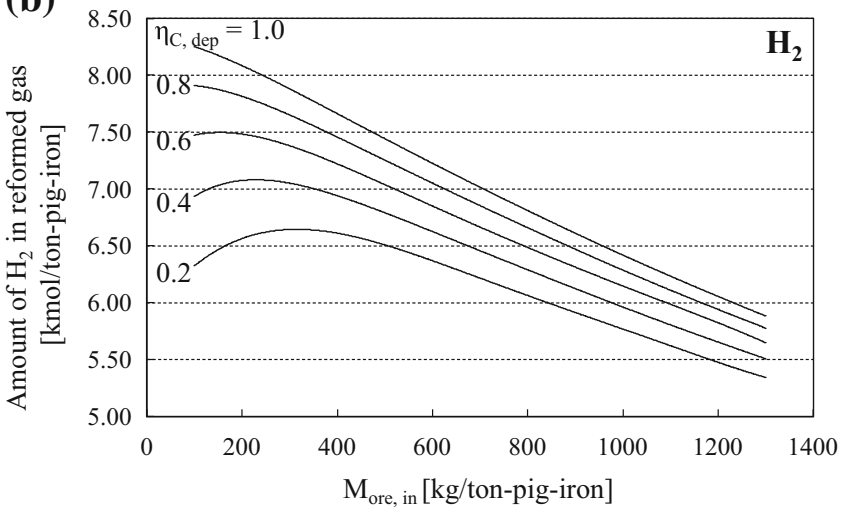

(d)

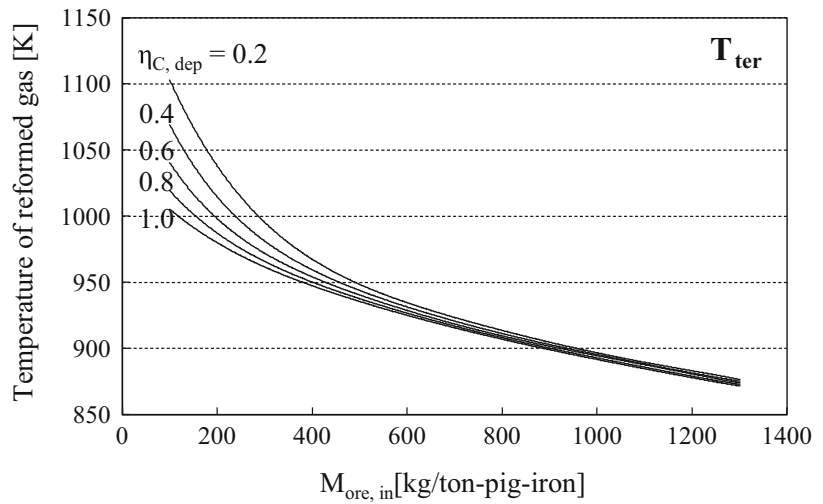

Fig. 4 Effects of $M_{\text {ore,in }}$ and $\eta_{\mathrm{C} \text {,dep }}$ on amounts of $\mathbf{a ~} \mathrm{CH}_{4}, \mathbf{b} \mathrm{H}_{2}$, and $\mathbf{c} \mathrm{CO}$, and $T_{\text {ter }}$ of the reformed gas after the $\mathrm{CVI} /$ reduction/reformer process in the proposed system 

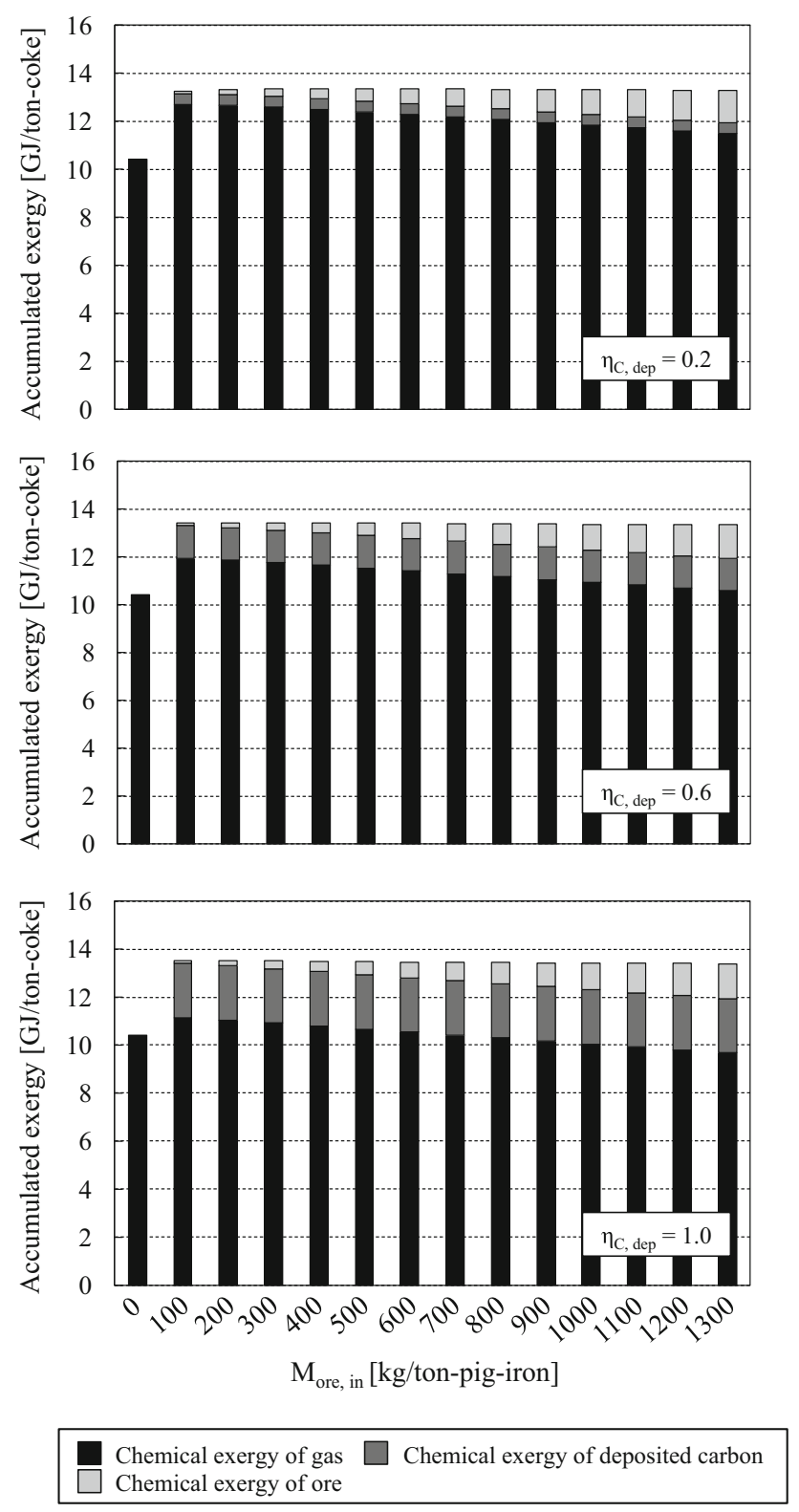

Fig. 5 Chemical exergy of gas, carbon deposited on ore, and the reduced ore for production of 1 ton of coke under all conditions, calculated by the Gibbs free energy minimization technique and the heat and mass balances. $M_{\text {ore, in }}=0$ indicates the conventional process

system. The chemical exergy of gas decreased as $M_{\text {ore,in }}$ and $\eta_{\mathrm{C} \text {,dep }}$ increased, while the chemical exergy of the ore increased in proportion to increases in $M_{\text {ore,in. }}$. This is primarily because hematite in the ore was completely reduced to magnetite in the proposed system; as a result, the chemical exergy of the gas was converted to the chemical exergy of the magnetite. In the CVI/Reduction/Reformer process, the exergy of the waste heat of the COG and slag was regenerated with the reforming of tar, and part of the chemical exergy of the reducing gas was converted to the chemical exergy of the magnetite.

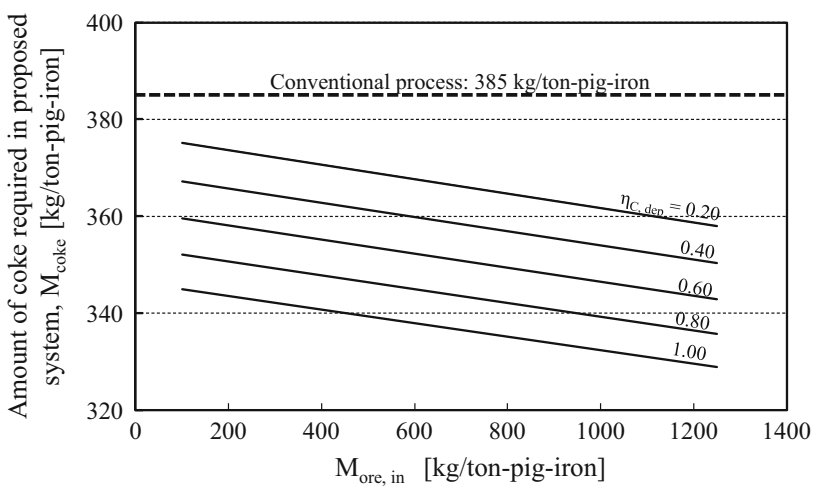

Fig. 6 Effects of $M_{\text {ore,in }}$ and $\eta_{\text {C,dep }}$ on $M_{\text {coke }}$ required to produce 1 ton of pig-iron in the proposed system (Case 2) with the value of the conventional system (Case 1) for comparison

Figure 6 shows the effects of $M_{\text {ore,in }}$ and $\eta_{\mathrm{C} \text {,dep }}$ on the $M_{\text {coke }}$ that was required to produce 1 ton of pig-iron in the proposed system. Clearly, the values under all conditions were lower than those for the conventional system. The values decreased in proportion to increases in both $\eta_{\mathrm{C} \text {,dep }}$ and $M_{\text {ore,in. }}$. These decreases occurred because increases in $\eta_{\mathrm{C} \text {,dep }}$ led directly to decreases in $M_{\text {coke }}$ and magnetite production increased in proportion to increases in $M_{\text {ore, in }}$ due to the reduction of hematite in the ore, as shown in Fig. 5. The minimum value of $M_{\text {coke }}$ in the analysis was $329 \mathrm{~kg} /$ ton-pig-iron, which was $14.5 \%$ less than that required by the conventional system at $\eta_{\mathrm{C}, \mathrm{dep}}=1.0$ and $M_{\text {ore,in }}=1300 \mathrm{~kg}$. The results clearly show that the proposed system offers great potential for decreasing the amount of coke required to produce 1 ton of pig-iron.

Figure 7 shows the effects of $M_{\text {ore,in }}$ and $\eta_{\text {C,dep }}$ on $\varepsilon_{\text {total }}$ per ton of pig-iron in the proposed system (Case 2) and the conventional process (Case 1). Values of $\varepsilon_{\text {total }}$ in the proposed system were larger than those for the conventional system under all conditions, even though $M_{\text {coke }}$ for the proposed system was smaller than for the conventional system. The exergy values decreased in proportion to increases of $M_{\text {ore,in }}$ and $\eta_{\mathrm{C} \text {,dep }}$. This occurred because $M_{\text {coke }}$ for the proposed system first decreased in proportion to increases in $M_{\text {ore,in }}$ and $\eta_{\mathrm{C} \text {,dep }}$ and, thereafter, increases in $M_{\text {ore,in }}$ led to increases in the sensible heat of the ore and a decrease in the chemical exergy of the gas owing to a decrease in the heat for reforming. The maximum total chemical exergy per production of 1 ton pig-iron in the analysis was $5.00 \mathrm{GJ} /$ ton-pig-iron, which was $14.2 \%$ greater than that of the conventional system, at $\eta_{\mathrm{C}, \text { dep }}=0.20$ and $M_{\text {ore,in }}=100 \mathrm{~kg}$.

Figure 8 shows the effects of $M_{\text {ore,in }}$ and $\eta_{\mathrm{C} \text {,dep }}$ on $\mathrm{MF}_{\mathrm{C} \text {,sup }}$ with a previously reported value for comparison [17]. The values were inversely proportional to $M_{\text {ore,in }}$ and increases in $\eta_{\mathrm{C} \text {,dep }}$. The results provided a minimum $M_{\text {ore,in }}$ value for each $\eta_{\text {C,dep }}$ by assessing whether the values were lower than 


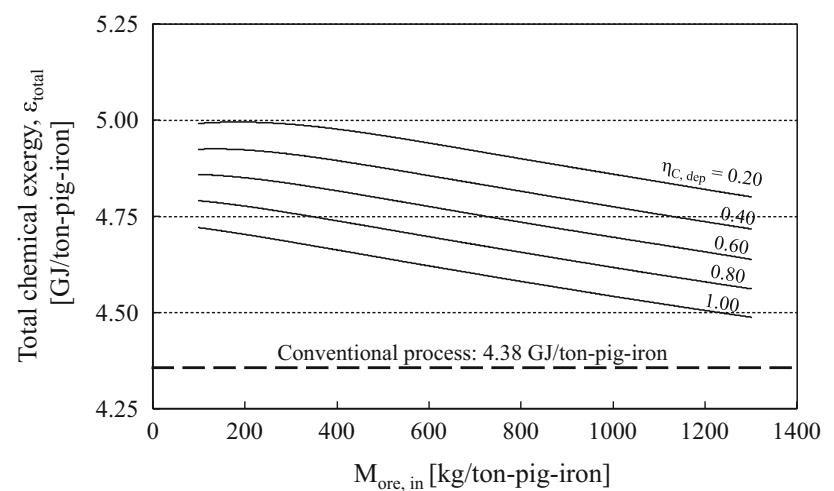

Fig. 7 Effects of $M_{\text {ore,in }}$ and $\eta_{\mathrm{C} \text {,dep }}$ on $\varepsilon_{\text {total }}$ per ton of pig-iron in the proposed system (Case 2) with the value for the conventional process (Case 1) shown for comparison

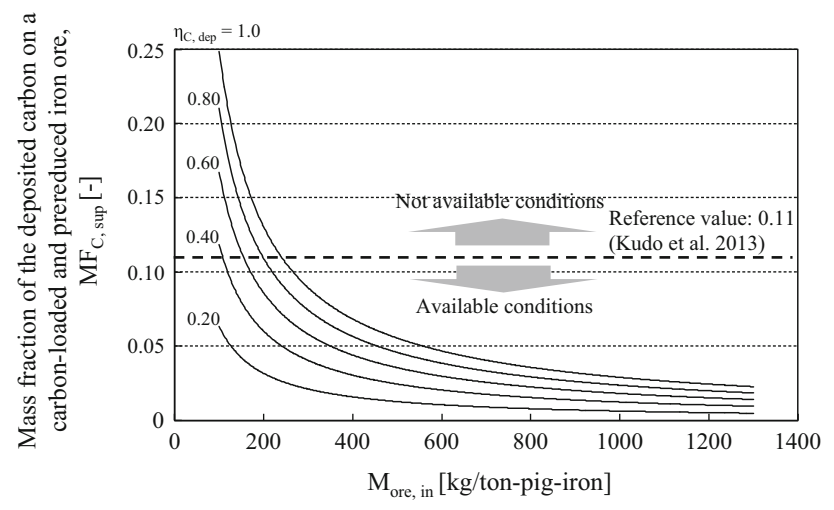

Fig. 8 Effects of $M_{\text {ore,in }}$ and $\eta_{\mathrm{C} \text {,dep }}$ on $\mathrm{MF}_{\mathrm{C} \text {,sup }}$ with a previously reported value [17] for comparison

previously reported. When the values were higher than the reported value, the system was classed as unrealistic because extremely high amounts of carbon were deposited and the values were impossible to achieve in real operations. The minimum $\mathrm{M}_{\text {ore,in }}$ values for $\eta_{\mathrm{C} \text {,dep }}=0.20,0.40,0.60,0.80$, and 1.0 were $100,108,154,200$, and $246 \mathrm{~kg}$, respectively. From the viewpoint of $\mathrm{MF}_{\mathrm{C} \text {,sup }}$, the proposed system can be designed using a wide range of $M_{\text {ore,in }}$ for each $\eta_{\mathrm{C} \text {,dep }}$.

Figure 9 shows the effects of $M_{\text {ore,in }}$ and $\eta_{\mathrm{C} \text {,dep }}$ on $Q_{\text {supply }}$ in the proposed system, also illustrating $Q_{\text {supply }}$ in the conventional process and the effect of dehydration on $Q_{\text {supply }}$ (Eq. 1). For each $\eta_{\mathrm{C} \text {,dep }}, Q_{\text {supply }}$ decreased in proportion to increases in $M_{\text {ore,in }}$ and $\eta_{\mathrm{C} \text {,dep }}$. These results can be explained by the decrease in $M_{\text {coke }}$ accompanying the increase in $\eta_{\mathrm{C} \text {,dep }}$ and $M_{\text {ore,in }}$, as shown in Fig. 6.

The decrease in $M_{\text {coke }}$ for the proposed system indicates that the values for the following parameters per ton of pigiron also decreased:

(1) the generation of tar and COG,

(2) the amount of heat required for coking, and

(3) the amount of heat generated from CDQ.

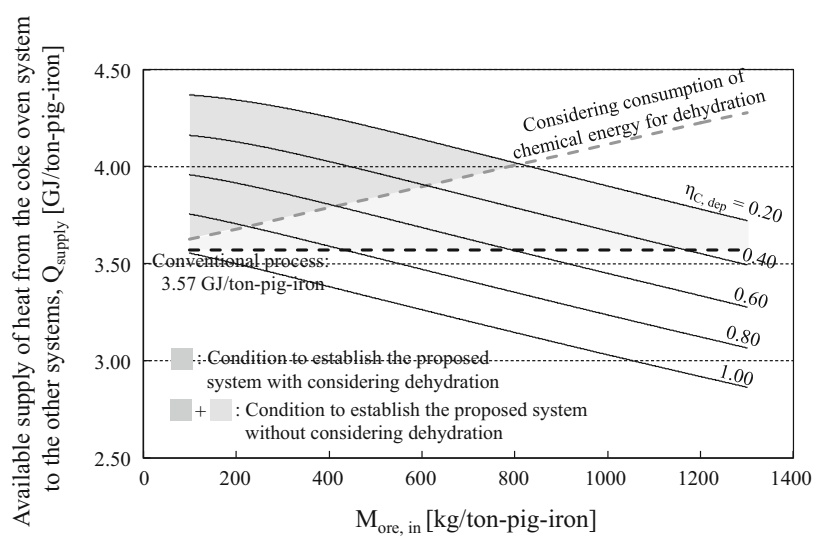

Fig. 9 Effects of $M_{\text {ore,in }}$ and $\eta_{\mathrm{C} \text {,dep }}$ on $Q_{\text {supply }}$ in the proposed system, shown with the value of $Q_{\text {supply }}$ for the conventional process and the effect of dehydration on $Q_{\text {supply }}$ (Eq. 1)

This is because these values are proportional to the amount of coke required.

The maximum $M_{\text {ore,in }}$ for each $\eta_{\mathrm{C} \text {,dep }}$ can be clarified, by checking whether the values were larger than the corresponding values for the conventional process (Eq. 14). From the viewpoint of $Q_{\text {supply }}$, the maximum values of $M_{\text {ore,in }}$ for $\eta_{\mathrm{C} \text {,dep }}=0.20,0.40,0.60,0.80$, and 1.0 were $1300,1162,804,438$, and $0 \mathrm{~kg}$, respectively. Furthermore, when the reaction heat of dehydration is considered, the maximum values of $M_{\text {ore, in }}$ for $\eta_{\mathrm{C}, \mathrm{dep}}=0.20,0.40,0.60$, 0.80 , and 1.0 were $808,605,419,232$, and $0 \mathrm{~kg}$, respectively.

From Figs. 8 and 9, we can determine the range over which the proposed system would be effective, considering the value of $M_{\text {ore,in }}$ for each $\eta_{\mathrm{C} \text {,dep }}$.

Table 3 lists the ranges of $M_{\text {ore,in }}$ required to establish the proposed system-the minimum $M_{\text {coke }}$ and the maximum total chemical exergy, with or without the dehydration process. For $\eta_{\mathrm{C} \text {,dep }}$ values between 0.20 and 0.80 , the conditions necessary to establish the proposed system were satisfied. The ranges were wider for smaller values of $\eta_{\mathrm{C} \text {,dep }}$. The results indicate that dehydration processes are very important for establishing the proposed system. Since the temperature of dehydration is low, about $723 \mathrm{~K}$, some exhaust heat can be applied without combustion of the reformed gas. The minimum $M_{\text {coke }}$ without considering dehydration was $348 \mathrm{~kg}$, which was $9.62 \%$ smaller than for the conventional system at $M_{\text {ore,in }}=438 \mathrm{~kg}$ and $\eta_{\mathrm{C} \text {,dep }}=0.80$. The minimum $M_{\text {coke }}$ for the proposed system considering dehydration was $351 \mathrm{~kg}$, which was $8.78 \%$ smaller than the conventional system, at $M_{\text {ore, in }}=232 \mathrm{~kg}$ and $\eta_{\mathrm{C} \text {,de- }}$ po $=0.80$. The maximum total chemical exergy was 5.00 GJ, which was $14.2 \%$ larger than that for the conventional system, at $M_{\text {ore,in }}=100 \mathrm{~kg}$ and $\eta_{\mathrm{C} \text {,dep }}=0.20$, with or without consideration of dehydration. 
Table 3 Range of $M_{\text {ore,in }}$ required to establish the proposed system, minimum coke requirement, and maximum total chemical exergy

\begin{tabular}{|c|c|c|c|c|}
\hline $\begin{array}{l}\eta_{\mathrm{C}, \mathrm{dep}} \\
(-)\end{array}$ & $\begin{array}{l}\text { Dehydration } \\
\text { process }\end{array}$ & $\begin{array}{l}\text { Range of } \\
M_{\text {ore,in }}(\mathrm{kg})\end{array}$ & $\begin{array}{l}\text { Minimum coke requirement } \\
\text { (kg/ton-pig-iron) }\end{array}$ & $\begin{array}{l}\text { Maximum chemical exergy } \\
\text { (GJ/ton-pig-iron) }\end{array}$ \\
\hline \multirow[t]{2}{*}{0.2} & Considering & $100-808$ & $365\left(M_{\text {ore, in }}=808 \mathrm{~kg}\right)$ & \multirow[t]{2}{*}{$5.00\left(M_{\text {ore, in }}=158 \mathrm{~kg}\right)$} \\
\hline & Not considering & $100-1300$ & $359\left(M_{\text {ore }, \text { in }}=1300 \mathrm{~kg}\right)$ & \\
\hline \multirow[t]{2}{*}{0.4} & Considering & $108-605$ & $361\left(M_{\text {ore,in }}=605 \mathrm{~kg}\right)$ & \multirow[t]{2}{*}{$4.94\left(M_{\text {ore }, \text { in }}=108 \mathrm{~kg}\right)$} \\
\hline & Not considering & $108-1162$ & $353\left(M_{\text {ore }, \text { in }}=1162 \mathrm{~kg}\right)$ & \\
\hline \multirow[t]{2}{*}{0.6} & Considering & $154-419$ & $356\left(M_{\text {ore, in }}=419 \mathrm{~kg}\right)$ & \multirow[t]{2}{*}{$4.86\left(M_{\text {ore }, \text { in }}=154 \mathrm{~kg}\right)$} \\
\hline & Not considering & $154-804$ & $351\left(M_{\text {ore, in }}=804 \mathrm{~kg}\right)$ & \\
\hline \multirow[t]{2}{*}{0.8} & Considering & $200-232$ & $351\left(M_{\text {ore, in }}=232 \mathrm{~kg}\right)$ & \multirow[t]{2}{*}{$4.77\left(M_{\text {ore,in }}=200 \mathrm{~kg}\right)$} \\
\hline & Not considering & $200-438$ & $348\left(M_{\text {ore, in }}=438 \mathrm{~kg}\right)$ & \\
\hline 1 & Considering & Not established & - & - \\
\hline
\end{tabular}

\section{Conclusions}

The purpose of this paper was to estimate the feasibility of the coproduction of carbon-loaded iron oxide and reformed COG using coal tar, limonite ore, and waste heat by process simulation, from the viewpoints of (1) the requirement for coke, $M_{\text {coke }}$, (2) the total chemical exergy, $\varepsilon_{\text {total }}$, (3) the mass fraction of deposited carbon on a carbon-loaded and prereduced iron ore, $\mathrm{MF}_{\mathrm{C} \text {,sup }}$, and (4) available supplies of heat from the coke oven system to other systems, $Q_{\text {supply }}$, under reasonable assumptions. The conclusions can be summarized as follows:

(1) The proposed system can help reduce $M_{\text {coke }}$ : the values decreased in proportion to increases in $\eta_{\mathrm{C}, \mathrm{dep}}$ and $M_{\text {ore,in }}$.

(2) The proposed system can help increase the total chemical exergy: the values decreased in proportion to increases in $M_{\text {ore,in }}$ and $\eta_{\mathrm{C}, \mathrm{dep}}$.

(3) Considering $\mathrm{MF}_{\mathrm{C} \text {,sup }}$ and $Q_{\text {supply }}$ as constraints, the required values of $M_{\text {ore,in }}$ were achieved when $\eta_{\mathrm{C} \text {,dep }}$ values were between 0.20 and 0.80 . The minimum $M_{\text {coke }}$ without considering dehydration was $348 \mathrm{~kg}$, which was $9.62 \%$ less than the corresponding value for the conventional system, at $M_{\text {ore,in }}=438 \mathrm{~kg}$ and $\eta_{\mathrm{C}, \mathrm{dep}}=0.80$. The minimum $M_{\text {coke }}$ for the proposed system considering dehydration was $351 \mathrm{~kg}$, which was $8.05 \%$ less than the corresponding value for the conventional system, at $M_{\text {ore,in }}=232 \mathrm{~kg}$ and $\eta_{\text {C,dep }}=0.80$. The maximum total chemical exergy was 5.00 GJ, which was $14.2 \%$ higher than the corresponding value for the conventional process, at $M_{\text {ore,in }}=158 \mathrm{~kg}$ and $\eta_{\mathrm{C} \text {,dep }}=0.20$, with or without consideration of dehydration.

The results of the present work contribute in the sustainability of ironmaking process because the suggested process can be a simultaneous solution of resource and energy problems.

\section{References}

1. Agency for Natural Resources and Energy (2012) http://www. enecho.meti.go.jp/english/index.htm. Accessed 15 Jan 2012

2. Akiyama T (2010) Preface to the "special issue on science and technologies for the effective use of unrecovered energy in steelworks". ISIJ Int 50:1227-1228

3. Akiyama T, Oikawa K, Shimada T, Kasai E, Yagi J-I (2000) Thermodynamic analysis of thermochemical recovery of high temperature wastes. ISIJ Int 40:288-291

4. Aktas S, Karakaya M, AvcI AK (2009) Thermodynamic analysis of steam assisted conversions of bio-oil components to synthesis gas. Int J Hydrogen Energy 34:1752-1759

5. Cahyono RB, Rozhan AN, Yasuda N, Nomura T, Hosokai S, Kashiwaya Y, Akiyama T (2013) Integrated coal-pyrolysis tar reforming using steelmaking slag for carbon composite and hydrogen production. Fuel 109:439-444

6. Barati M, Esfahani S, Utigard T (2011) Energy recovery from high temperature slags. Energy. 36(9):5440-5449

7. Cahyono RB, Rozhan AN, Yasuda N, Nomura T, Hosokai S, Kashiwaya Y, Akiyama T (2013) Catalytic coal-tar decomposition to enhance reactivity of low-grade iron ore. Fuel Process Technol 113:84-89

8. Cahyono RB, Rozhan AN, Yasuda N, Nomura T, Purwanto H, Akiyama T (2013) Carbon deposition using various solid fuels for ironmaking applications. Energy Fuels 27:2687-2692

9. Cahyono RB, Yasuda N, Nomura T, Akiyama T (2014) Optimum temperatures for carbon deposition during integrated coal pyrolysis-tar decomposition over low-grade iron ore for ironmaking applications. Fuel Process Technol 119:272-277

10. Harding S, Floudas C (2000) Phase stability with cubic equations of state: Global optimization approach. AIChE J 46:1422-1440

11. Hata Y, Purwanto H, Hosokai S, Hayashi J, Kashiwaya Y, Akiyama T (2009) Biotar ironmaking using wooden biomass and nanoporous iron ore. Energy Fuels 23:1128-1131

12. Hosokai S, Matsui K, Okinaka N, Ohno K-I, Shimizu M, Akiyama T (2012) Kinetic study on the reduction reaction of biomass-tar-infiltrated iron ore. Energy Fuels 26:7274-7279

13. The Iron and Steel Institute of Japan (2007) Research and study of future technology for reducing $\mathrm{CO}_{2}$ emission in iron and steel manufacturing process. The Iron and Steel Institute of Japan, Tokyo

14. Ishida M (2002) Thermodynamics made comprehensible. Nova Science Publishers, Huntington

15. Kasai E, Kitajima T, Akiyama T, Yagi J, Saito F (1997) Rate of methane-steam reforming reaction on the surface of molten $\mathrm{BF}$ slag: for heat recovery from molten slag by using a chemical reaction. ISIJ Int 37:1031-1036 
16. Kashiwaya Y, Akiyama T (2010) Nanocrack formation in hematite through the dehydration of goethite and the carbon infiltration from Biotar. J Nanomater 2010:18

17. Kudo S, Sugiyama K, Norinaga K, Li C-Z, Akiyama T, Hayashi J-I (2013) Coproduction of clean syngas and iron from woody biomass and natural goethite ore. Fuel 103:64-72

18. Li P, Yu Q, Qin Q, Liu J (2011) Adaptability of coal gasification in molten blast furnace slag on coal samples and granularities. Energy Fuels 25:5678-5682

19. Nordgreen T, Liliedahl T, Sjöström K (2006) Metallic iron as a tar breakdown catalyst related to atmospheric, fluidised bed gasification of biomass. Fuel 85:689-694
20. Qin Y-L, Qiu G-B, Bai C-G, Lv X, Deng Q-Y (2011) Development of studies on sensible heat recovery from blast furnace slag by chemical methods. China Metall 21:1-7

21. Tomorrow's Ironmaking (2012) Iron Nugget Xchange. http:// www.ironxch.com/technology03.html. Accessed 20 Feb 2012

22. Uddin A, Tsuda H, Wu S, Sasaoka E (2008) Catalytic decomposition of biomass tars with iron oxide catalysts. Fuel 87:451-459 